\title{
03
}

\section{REVITALISASI PENDIDIKAN MULTIKULTURAL DALAM PEMBELAJARAN SEJARAH}

Sudrajat

\section{A. Pengantar}

Masyarakat Indonesia adalah masyarakat plural yang multikultur. Menurut Suryadinata (Farida Hanum, 2012) Indonesia terdiri atas kurang lebih 600 suku bangsa dengan identitasnya masing-masing serta kebudayaannya yang berbeda-beda. Selain dari kehidupan suku-suku tersebut yang terkonsentrasi pada daerah-daerah tertentu, terjadi pula konsentrasi suku-suku di tempat lain karena migrasi atau karena mobilisasi penduduk yang cepat. Melalui sensus tahun 2000 tercatat 101 suku bangsa di Indonesia dengan jumlah total penduduk 201.092.238 jiwa. Dengan kenyataan tersebut, maka Indonesia merupakan negara multikultur apalagi bila ditambah dengan migran atau warga keturunan. Sebagai sebuah entitas, multikultur merupakan sebuah keniscayaan, sebabnya adalah setiap manusia pasti mempunyai perbedaan yang mencirikan antara manusia satu dengan lainnya.

Perbedaan merupakan fitrah yang harus diterima (taken for granted) sebagai bunga-bunga kehidupan. Perbedaan akan semakin menambah variasi sehingga kehidupan manusia semakin bermakna, dinamis, dan dapat berkembang dengan baik. Jadi masyarakat multikultural merupakan realitas yang harus diterima oleh setiap bangsa. Di dunia ini hampir tidak ada masyarakat monokultural, bahkan sejarah telah mencatat bahwa setiap upaya untuk menciptakan monokultural dengan berbagai macam bentuk telah gagal karena pada hakekatnya masyarakat multikultural merupakan sunatullah (Zamroni, 2011b: 31).

Namun perbedaan juga dapat mendatangkan malapetaka karena ia rawan dengan makna dan persepsi. Oleh karenanya, dengan jumlah etnis yang begitu banyak, benturan, intrik, dan perselisihan yang didasarkan pada etnis, agama, dan identitas kultural lainnya sangat potensial terjadi di negara ini. Ketika interaksi sosial antar kelompok yang berbeda tersebut dihinggapi sengan semangat superioritas dan primordialisme sempit, yaitu semangat yang menilai kelompoknya adalah yang paling benar, paling baik, dan paling unggul sedangkan kelompok lain sebagai pelengkap saja, maka sebenarnya benih-benih perpecahan dan keretakan dari bangun negara bangsa segera dimulai. Kerusuhan di Sambas, Lampung, Poso, dan beberapa tempat lain merupakan cermin dari kegagalan pemerintah negeri ini dalam mengelola keberagaman. Apabila hal ini dibiarkan begitu saja maka kita akan menghadapi permasalahan yang lebih besar yang mengancam stabilitas dan integritas nasional.

Pendidikan bisa menjadi starting point untuk mengurai benang kusut yang dihadapi oleh bangsa kita. Pendidikan sudah selayaknya berperan dalam menyelesaikan konflik yang sudah terjadi secara massif di masyarakat. Minimal pendidikan harus mampu memberikan penyadaran 
(conciousness) kepada masyarakat bahwa konflik bukanlah hal yang baik untuk dibudayakan. Pendidikan sudah selayaknya memberikan tawaran yang mencerdaskan dalam menyelesaikan permasalahan yang terjadi di masyarakat. Dalam kaitan dengan hal tersebut pendidikan harus dapat berperan sebagai media transformasi sosial, budaya, dan multikulturalisme (Choirul Mahfud, 2010: 5). Dalam pandangan Zamroni (2007) pendidikan juga harus dapat berperan sebagai social reconstruction yaitu pendidikan yang mampu memahami struktur sosial masyarakat dan melakukan perubahan yang diperlukan.

Uraian di atas sejalan dengan pandangan Paulo Freire (Firdaus M Yunus, 2007: 1) yang menyatakan bahwa pendidikan merupakan salah satu upaya untuk mengembalikan fungsi manusia menjadi manusia agar terhindar dari berbagai bentuk penindasan, kebodohan sampai kepada ketertinggalan. Manusia sebagai pusat pendidikan harus menjadikan pendidikan sebagai alat pembebasan untuk mengantarkan manusia menjadi makhluk yang bermartabat. Dalam proses ini pendidikan dimaknai sebagai proses pembentukan kepribadian dan pengembangan seseorang sebagai makhluk individu, sosial, susila, dan makhluk yang beragama. Kesemuanya menghendaki manusia menjadi makhluk yang seimbang sehingga diharapkan pendidikan dapat menyediakan proses untuk mencapai tujuan tersebut. Pengembangan manusia sebagai makhluk sosial dan susila menyiratkan sebuah titah pembudayaan manusia untuk hidup berdampingan dengan orang lain dalam mengembangkan suasana kehidupan bermasyarakat yang kondusif, adil, dan terbuka.

Masyarakat Indonesia yang multikultur memerlukan kehidupan yang demikian itu. Lebih jauh lagi masyakarakat pelu didorong untuk memahami dan menerima perbedaan yang dimiliki oleh setiap kelompok. Permasalahannya menjadi sedemikian pelik karena tampaknya tidak usaha dari pemerintah untuk menanamkan kesadaran multikulturalisme. Hal ini tampak dari penanganan yang terkesan tidak serius terhadap konflik SARA. Pemerintah juga tidak serius untuk melakukan usaha preventif agar konflik horisontal tidak terulang kembali. Yang biasa dilakukan adalah usaha politis-militeristik yang menganggap konflik horisontal sebagai gejala politik, ekonomi, dan peristiwa hukum. Konflik selalu dimaknai sebagai peristiwa hukum yang menyeret pelaku ke meja hijau untuk kemudian dikenakan hukuman sesuai dengan KUHP. Selain itu peristiwa konflik juga diselesaikan secara politis (dikaitkan dengan upaya menggoyang kedudukan penguasa) atau dikaitkan dengan kecemburuan sosial akibat perbedaan status ekonomi. Dengan demikian penanganan yang dilaksanakan sama sekali tidak menyentuh akar multikulturalisme sehingga konflik serupa rawan terulang kembali.

Pertanyaan kemudian apakah kesadaran multikulturalisme dapat ditanamkan di dalam masyarakat kita. Dalam kaitan ini ada sedikit ilustrasi dari sebuah refleksi historis. Di wilayah Jawa Barat ternyata tidak ada nama jalan, monumen maupun tempat-tempat bersejarah yang menggunakan nama Hayam Wuruk atau Gadjah Mada. Padahal di hampir 
sebagian besar wilayah Nusantara banyak nama jalan, monumen atau bahkan tempat-tempat penting yang menggunakan nama tersebut. Tidak ada keberanian para pengambil keputusan di Jawa Barat, entah gubernur, bupati, walikota atau siapapun, untuk menggunakan nama Gadjah Mada atau Hayam Wuruk sebagai nama tempat di wilayahnya. Hayam Wuruk dan Gadjah di mata orang Sunda sebagai mayoritas suku yang tinggal di Jawa Barat, tak lebih sebagai sosok pengkhianat. Peristiwa perang Bubat yang ditandai dengan pembantaian seluruh keluarga kerajaan Pajajaran oleh pasukan Majapahit, menjadi peristiwa traumatis bagi orang Sunda.

\section{B. Urgensi Kesadaran Multikulturalisme}

Sebenarnya yang dibutuhkan oleh bangsa yang multikultur seperti Indonesia adalah usaha penanaman kesadaran multikultur. Multikulturalisme merupakan sebuah pengakuan atas pluralisme dan multikulturalisme dalam kehidupan berbangsa dan bernegara sehingga tercipta pengakuan dan penghargaan atas eksistensi perbedaan tersebut. Multikulturalisme merupakan sebuah konsep dimana sebuah komunitas dalam konteks kebangsaan dapat mengakui keberagaman, perbedaan dan kemajemukan budaya, baik ras, suku, etnis, dan agama (Choirul Mahfud, 2010: 91). Konsep ini memberikan pemahaman bahwa sebuah bangsa yang plural dan majemuk adalah bangsa yang dipenuhi dengan budaya-budaya yang beragam. Lebih jauh dikemukakan oleh Choirul Mahfud (2010: 94) bahwa ada lima macam multikulturalisme yaitu:

1) Multikulturalisme isolasionis yang mengacu pada masyarakat dimana berbagai kelompok kultural menjalankan hidup secara otonom dan terlibat dalam interaksi yang minimal.

2) Multikultualisme akomodatif dimana masyarakat dengan kultur yang dominan membuat penyesuaian dan akomodasi bagi kaum minoritas.

3) Multikulturalisme otonomis dimana kelompok-kelompok kultural utama berusaha mewujudkan kesetaraan dan menginginkan otonomi dalam kerangka politik yang dapat diterima secara kolektif.

4) Multikulturalisme kritikal yaitu kelompok tidak peduli dengan kehidupan otonom tetapi menciptakan kultur kolektif.

5) Multikulturalisme kosmopolitan paham yang berusaha menghapus batas kultural dan menciptakan sebuah masyarakat yang tidak terikat dengan budaya tertentu.

Kultur Indonesia sebagian besar merupakan isolated culture dimana jarang terjadi persentuhan antar kultur. Sedangkan kultur lainnya adalah accomodative culture dengan membuka toleransi bagi kultur lain (Tatang Amirin, 2012: 10). Dalam konteks tersebut kultur Jawa dapat dikatakan sebagai kultur besar yang mendominasi kultur lainnya. Namun Jawa tidak menindas, ia mengakomodasi kultur lain sehingga dapat hidup berdampingan dalam sebuah kerangka politik yang disebut Negara Kesatuan Republik Indonesia. Apabila kultur Jawa mendominasi dan 
menindas kultur lain, maka tidak mungkin bahasa Indonesia dapat menjadi bahasa nasional sampai sekarang (Zamroni, 2011: 160).

Konsep multikulturalisme dalam konteks ini tidak hanya sebatas pada konsep keanekaragaman suku bangsa atau kebudayaan masyarakat yang plural, namun menekankan pada keanekaragaman kebudayaan dalam kesederajatan. Multikulturalisme merupakan konsep yang datang dari Barat yang mana pada perkembangannya konsep dan teori multikulturalisme mempunyai pengaruh di negara-negara Asia berkat promosi yang maha luas dari akademisi, pemerintah dan organisasi internasional. Gerakan multikultural muncul pada tahun 1970-an, pertama kali muncul di Kanada, Australia, Amerika Serikat, Inggris, Jerman dan berkembang di negara Eropa lainnya. Dalam kaitannya dengan multikulturalisme di negara-negara Asia, Kymlicka \& Baogang (2005: 1) menulis:

All of the major ethical and religious traditions in the region, from Confucian and Budhist to Islamic and Hindu have their own conceptions of the value of tolerance, and their own recipes for sustaining unity admits diversity. These traditions continue to shape people's beliefs and practices in the region. The legacies of colonialism and national liberation struggles also exercise a powerful influence on how issues of ethnocultural diversity are understood.

Dalam konteks Indonesia multikulturalisme selalu dikaitkan keberagaman etnis, agama, bahasa, warna kulit, dan lain sebagainya. Secara historis pemerintahan Orde Baru di bawah kepemimpinan Soeharto menganjurkan monokulturalisme dan menganggap tabu multikulturalisme yang disebutnya dengan terminologi SARA (suku, agama, dan ras). Seiring dengan semangat reformasi yang berbarengan dengan proses otonomisasi dan desentralisasi kekuasaan terjadi peningkatan gejala "provinsialisme" yang identik dengan etnisitas. Oleh karenanya muncul semangat egosentrisme, etnosentrisme yang di kemudian hari menimbulkan permasalahan rumit. Tragedi kemanusiaan pada era 2000-an di berbagai daerah seperti Poso, Ambon, Sambas, Madura, dan lain-lain merupakan fakta yang tidak terbantahkan bahwa semangat otonomisasi dan desentralisasi yang tidak dibarengi dengan kesadaran multikulturalisme menimbulkan permasalahan baru yang lebih rumit untuk dipecahkan. Padahal apabila kita berkaca pada sejarah berdirinya bangsa Indonesia, para founding fathers kita telah memberikan contoh bagaimanakah mereka merekonstruksi bekas wilayah Hindia Belanda ini menjadi sebuah bangsa dengan sikap toleransi, penuh pemahaman dan mementingkan keutuhan bangsa dan negara.

Semboyan "Bhineka Tunggal Ika" yang berarti berbeda-beda tetapi tetap satu menjadi tepat untuk menggambarkan realitas ke-Indonesiaan itu. Ungkapan tersebut mengisyaratkan kemauan kuat, baik di kalangan para pendiri negara, pemimpin maupun di kalangan rakyat, untuk mencapai suatu bangsa dan negara Indonesia yang bersatu. Sekalipun 
terdapat unsur-unsur yang berbeda namun kemauan untuk mempersatukan bangsa sesungguhnya mengatasi keanekaragaman itu tanpa menghapuskannya atau mengingkari-nya. Keinginan bersama untuk tetap menghargai perbedaan dan memahaminya sebagai realitas kehidupan menjadi potensi kesadaran pluralisme dan multikulturalisme di Indonesia. Hal tersebut dapat membentuk kebudayaan Indonesia masa depan yang bertumpu pada kesadaran akan kemajemukan.

Permasalahan yang dihadapi dewasa ini adalah bagaimanakah semangat dan kesadaran multikulturalisme dapat dipahami oleh semua elemen bangsa ini. Dalam kaitan dengan pertanyaan ini pendidikan merupakan salah satu sarana efektif untuk menanamkan dan memahamkan kesadaran multikulturalisme bagi semua peserta didik. Pendidikan sebagai pengalaman belajar yang berlangsung dalam lingkungan budaya maupun lingkungan alam merupakan akses terpenting untuk melakukan rekayasa budaya. Kebudayaan memegang peranan penting sebagai proses untuk mengatasi karakteristik hewani yang ada dalam diri manusia, suatu karakter yang berkenaan dengan homonisasi. Yvon Ambroise (Kaswardi, 1993: 18) menambahkan bahwa proses humanisasi merupakan usaha untuk melebihi kehidupan hewani dan membangun atasnya sesuatu yang tidak sama, kreatif, dan yang memperkaya dalam diri seorang pribadi.

Pendidikan merupakan starting point untuk melakukan rekonstruksi budaya multikultur dalam masyarakat yang demokratis. Zamroni (2007: 76) menyatakan bahwa pendidikan merupakan wahana untuk menanamkan hakikat dan praktik pluralistis bagi peserta didik. Filsafat pluralisme dalam pendidikan tidak terbatas pada aspek pendidikan semata, melainkan mencakup pula berbagai aspek kemasyarakatan yang mau tidak mau akan mempengaruhi proses pendidikan. Dengan demikian diperlukan upaya sistematis dan sinergis antar elemen sehingga masyarakat pluralis-demokratis dapat diwujudkan.

\section{Wacana Pendidikan Multikultural}

Sebagai wacana baru terminologi pendidikan multikultur sesungguh-nya belum begitu jelas dan masih terdapat perdebatan diantara para pakar. Hilda Hernandez (Choirul Mahfud, 2010: 176) menyatakan pendidikan multikultur sebagai perspektif yang mengakui realitas politik, sosial, dan ekonomi yang dialami oleh masing-masing individu dalam pertemuan manusia yang kompleks dan beragam secara kultur, dan merefleksikan pentingnya budaya, ras, seksualitas, gender, agama, status sosial ekonomi, dan pengecualian-pengecualian dalam proses pendidikan. Dalam pandangan ini pendidikan semestinya memberikan ruang untuk proses transformasi pengetahuan dan nilai-nilai multikulturalisme dengan cara menciptakan penghormatan terhadap realitas yang beragam dari peserta didik.

Senyampang dengan uraian di atas, James A. Bank (2010: 3) menyatakan bahwa pendidikan multikultural setidaknya meliputi tiga hal 
yaitu: ide atau konsep, sebuah gerakan reformasi dalam bidang pendidikan, dan sebuah proses.

Multicultural education incorporates the idea that all students - regardless of their gender, social class, and ethnic, racial, or cultural characteristicsshould have an equal opportunity to learn in school. Another important idea in multicultural education is that some students, because of these characteristics, have a better chance to learn in schools as they are currently structured than do students who belong to other groups or who have different cultural characteristics.

Selanjutnya Banks (2001) menyakini bahwa pendidikan multikultural merupakan suatu rangkaian kepercayaan (set of beliefs) dan penjelasan yang mengakui dan menilai pentingnya keragaman budaya dan etnis di dalam bentuk gaya hidup, pengalaman sosial, identitas pribadi, kesempatan pendidikan dari individu, kelompok maupun negara. Lebih lanjut James A. Banks (2007: 50) mengungkapkan:

Individual and groups frequently oppose legally mandate desegregated schools for diverse and complex reason, including fears of racial groups, a strong commitment to the concept of the neighborhood school, a belief that the burden for desegregating schools falls primarily on minority students and parents, and fears that the quality of education in the schools will drop when they become racially integrated.

Ahli lain yang perlu diperhatikan pendapatnya adalah Sleeter \& Grant, dan Smith (Zamroni, 2011a: 144) mendefinisikan pendidikan multikultural sebagai suatu pendekatan progresif untuk melakukan transformasi pendidikan yang secara holistik memberikan kritik dan menunjukkan kelemahan-kelemahan, kegagalan dan diskriminasi yang terjadi di dunia pendidikan. Sedangkan bagi Nieto (Zamroni, 2011a: 144) pendidikan multikultural merupakan suatu bentuk pendidikan yang bertumpu pada keadilan sosial, kesetaraan pendidikan dan suatu dedikasi guna memberikan pengalaman belajar dimana seluruh siswa dapat mencapai perkembangan secara optimal. Secara umum pendidikan multikultural dipahami sebagai reformasi pendidikan yang mengedepankan keadilan sosial bagi semua kelompok di dalam masyarakat tanpa memandang identitas dan latar belakang siswa yang beragam agar tercapai tujuan pendidikan secara optimal.

Sehubungan dengan hal tersebut, akhir-akhir ini muncul wacana tentang pendidikan multikultural di Indonesia. Sebagaimana diberitakan Kompas (02/09/2004) bahwa saat ini perlu dibangun konsep pendidikan multikultural. Dalam pandangan Zamroni (2011a: 115-116) rekayasa sosial lewat pendidikan formal perlu dikaji secara mendalam. Artinya perlu ada usaha di lingkungan sekolah untuk menanamkan akan kesadaran hidup dalam masyarakat multikultur dan mengembangkan sikap tenggang rasa dan toleransi guna mewujudkan kebutuhan serta kemampuan bekerjasama dengan segala perbedaan yang ada. Sekolah harus dilihat sebagai suatu 
masyarakat, masyarakat kecil. Cara pandang sekolah sebagai masyarakat kecil ini mempunyai implikasi bahwa siswa dipandang sebagai individu yang mempunyai karakteristik yang terwujud dalam bakat dan minat serta aspirasi yang berbeda-beda sekaligus memiliki kebebasan. Perbedaan yang dimiliki masing-masing individu dari perspektif multikultural dan juga perspektif global memberikan tekanan bahwa sekolah harus memperhatikan: a) setiap siswa memiliki kebutuhan perkembangan yang berbeda-beda, termasuk kebutuhan personal dan sosial, b) kebutuhan vokasi dan karier, c) kebutuhan psikologis dan perkembangan moralspiritual (Zamroni, 2011b: 117).

Wacana pemikiran tentang pendidikan multikultural dilatarbelakangi oleh beberapa hal salah satunya adalah globalisasi. Tilaar (Choirul Mahfud, 2010: 183) bangsa yang tidak mempunyai strategi untuk mengelola kebudayaan yang mendapat tantangan dari globalisasi sedemikian dahsyatnya, dikhawatirkan akan mudah terbawa arus hingga akhirnya kehilangan jati diri baik lokal maupun nasional. Dalam kerangka tersebut, pendidikan multikultural hendaknya dijadikan sebagai strategi untuk mengelola kebudayaan dengan menawarkan strategi transformasi budaya yang ampuh yaitu melalui mekanisme pendidikan yang menghargai perbedaan budaya.

Dalam konteks penyelenggaraan pendidikan di Indonesia, UU No 20 Tahun 2003 (Bab III Pasal 4) dinyatakan bahwa pendidikan diselenggarakan secara demokratis dan berkeadilan serta tidak diskriminatif dengan menjunjung tinggi hak asasi manusia, nilai keagamaan, nilai kultural, dan kemajemukan bangsa. Dengan melihat hal tersebut, maka sebenarnya spirit multikulturalisme telah ada dalam semangat penyelenggaraan pendidikan. Namun yang dibutuhkan tidak sekadar justifikasi legal formal, melainkan aksi nyata dari segenap komponen pendidikan, baik pengambil keputusan, maupun para guru dan tenaga kependidikan di lapangan. Pendidikan multikul-tural tidak sekadar ide atau paradigma, meskipun hal tersebut penting, tetapi akan lebih bermakna apabila ia merupakan gerakan reformasi pendidikan yang dapat memberikan kontribusi positif.

Diperlukan terobosan-terobosan penting untuk mengubah paradigma pendidikan, sehingga wacana pendidikan mutikultur mendapatkan porsi yang memadai. Hal ini penting mengingat pendidikan multikultural diyakini dapat menjadi solusi nyata bagi konflik dan disharmoni yang kerap kali terjadi di masyarakat Indonesia. Penyelenggaraan pendidikan multikultural dianggap berhasil bila dalam diri siswa terbentuk sikap hidup toleran, tidak bermusuhan dan tidak berkonflik yang disebabkan oleh perbedaan budaya, suku, bahasa, agama, dan adat istiadat (Choirul Mahfud, 2010: 217). Pendidikan multikultural tidak harus diwujudkan dalam bentuk mata pelajaran, akan tetapi lebih efektif bila diintegrasikan ke dalam mata pelajaran lain seperti IPS, PKn, dan pelajaran lainnya. Dalam hal ini Gay (Zamroni, 2011b: 150) menyatakan bahwa amat keliru kalau melaksanakan pendidikan 
multikultural harus dalam bentuk mata pelajaran yang terpisah atau monolitik. Sebaiknya pendidikan multikultural diperlakukan sebagai pendekatan untuk memajukan pendidikan secara utuh dan menyeluruh. Ia dapat diberlakukan sebagai alat bantu untuk menjadikan warga negara memiliki jiwa toleran, bersifat inklusif, mempunyai semangat kesetaraan, dan senantiasa berpendirian bahwa suatu masyarakat akan lebih baik apabila semua warga memberikan kontribusi sesuai dengan kemampuan dan kesempatan yang dimilikinya. Inilah paradigma yang harus dipahami oleh setiap elemen pendidikan, sehingga implementasi pendidikan multikultural dalam pendidikan dan persekolahan tidak memerlukan prosedur yang rumit, tetapi yang diperlukan adalah kesadaran, kemauan, komitmen dan semangat untuk melakukan perubahan ke arah yang lebih baik.

\section{Pembelajaran Berbasis Multikultur}

Wacana pendidikan multikultural sudah selayaknya mendapat perhatian dari semua kalangan yang terkait dengan dunia pendidikan. Dukungan dan komitmen dari semua pihak merupakan langkah awal untuk mewujudkan pendidikan yang pluralis dan demokratis yang dapat berimplikasi pada terbentuknya masyarakat yang plural-demokratis juga. Bruch dkk (2004: 3) menyatakan bahwa pendidikan multikultural sangat baik diimplementasikan untuk persekolahan dalam masyarakat yang demokratis, karena memungkinkan seluruh warga negara berkontribusi dalam transformasi sosial yang membuat demokrasi semakin berkembang.

Salah satu elemen yang paling diperhatikan dalam mengimplementasikan pendidikan multikultural adalah guru, karena mereka merupakan aktor yang berhadapan langsung dengan peserta didik. Untuk itu guru harus mempunyai pemahaman yang memadai mengenai konsep dan paradigma pendidikan multikultural. Perlu ditekankan kepada guru bahwa pendidikan multikultural tidak hanya memperkenalkan kultur lain kepada peserta didik, akan tetapi juga perlu menciptakan iklim yang multicultural oriented yang mengedepankan keadilan sosial bagi peserta didik. Tujuannya adalah untuk mempersiapkan warga negara di masa depan untuk melakukan rekonstruksi masyarakat yang dapat melayani semua kebutuhan kelompok khususnya kelompok yang berbeda dari kulit berwarna, miskin, wanita, dan penyandang cacat (Banks, 2005: 71).

Upaya guru untuk mempersiapkan diri sebagai pengajar pendidikan multikultural adalah dengan melakukan transformasi diri dalam rangka menjadi pribadi yang multikultur. Guru dapat memulai dengan menjawab pertanyaan-pertanyaan tentang identitas dirinya, dan bagaimakah sikapnya terhadap siswa-siswanya yang beragam dalam etnis, agama, latar belakang sosial-ekonomi dan kemampuannya. Dalam tahap ini guru harus menemukan sebuah jawaban dan meneguhkan komitmen untuk memperlakukan siswa secara adil tanpa memandang etnis, agama, latar belakang yang berbeda-beda. Hal ini senada dengan apa yang disampaikan oleh Linda Darling Hammond, ea. (2002: 3) ... crossing 
boundaries is essential to social learning. Teachers and schools that educate well actively strive to understand rather than to suppress diversity. In this way they build a larger and stronger common ground.

Hal kedua yang perlu dilakukan oleh guru dalam rangka transformasi diri menurut Lisa A Jones (2004: 17) adalah: 1) mengambil peran sebagai agen perubahan, dan 2) menjadi model yang bertanggungjawab dalam melayani masyarakat. Dalam fungsinya sebagai pelayan masyarakat yang multikultur, guru harus dapat menunjukkan sikap yang adil dan menghilangkan prasangka terhadap kelompok lain. Hal ini penting mengingat peserta didik berangkat dari latar belakang yang berbeda. Mereka datang dari kelompok sosial ekonomi yang berbeda, etnis, agama, dan kultur yang berbeda pula.

Di samping itu hal yang tidak kalah pentingnya adalah perlunya kesabaran dalam melayani siswa khususnya untuk siswa dengan kemampuan rendah atau siswa dengan kebutuhan khusus seperti penyandang cacat. Hal ini tentunya langkah sulit yang harus dilakukan oleh guru yang akan sangat menentukan ketercapaian tujuan pendidikan multikultural. Salah seorang pionir pendidikan multikultural Geneva Gay (Zamroni, 2011a: 145) melihat penting dan perlunya pendidikan multikultural adalah untuk memberikan pelayanan pendidikan yang meningkatkan prestasi secara optimal bagi siswa yang mengalami keterbelakangan. Dengan demikian pendidikan multikultural mempunyai perspektif holistik tidak saja memberikan perlakuan yang adil tanpa prasangka tetapi juga meningkatkan prestasi yang maksimal bagi peserta didiknya.

Langkah berikutnya guru harus mempunyai desain pembelajaran berbasis multikultur. Dalam merumuskan tujuan pembelajaran sebaiknya guru mementingkan tujuan afektif serta psikomotor yang bermuara pada jalinan kerjasama antar siswa yang berbeda-beda. Untuk mengajarkan materi pembelajaran guru dapat menggunakan strategi pembelajaran cooperativelearning dengan berbagai variasinya. Dalam sebuah penelitian yang dilakukan di sebuah sekolah dasar di Yogyakarta, terbukti pada strategi ini dapat meningkatkan jalinan kerjasama di antara siswa dengan latar belakang yang beragam dan keterbelakangan (Sudrajat, 2011). Strategi pembelajaran tersebut juga dapat mengurangi prasangka terhadap siswa lain yang berbeda agama serta menghilangkan eksklusivitas siswa dari latar belakang ekonomi yang mapan.

Kendala yang dihadapi untuk mengimplementasikan pendidikan multikultur terletak pada lemahnya kemauan dan komitmen para pemangku kepentingan, kepala sekolah, kepala dinas, bupati/walikota, dan gubernur/kepala daerah. Kepala daerah dan kepala dinas pendidikan belum menjadikan pendidikan sebagai solusi untuk mengeliminasi konflik dan mempromosikan keadilan sosial. Kendala lainnya orientasi pembelajaran yang mengarah pada kognitif juga menjadi penghambat yang cukup serius. Oleh karenanya tidak mengherankan apabila tawuran 
antar pelajar, bahkan antar fakultas di perguruan tinggi sering terjadi bahkan menjadi budaya dalam masyarakat kita.

Integrasi pendidikan multikultur pada muaranya akan menciptakan kultur yang sehat dalam sekolah. Interaksi sosial antara siswa menjadi semakin kondusif, demikian juga interaksi antara guru-siswa menjadi lebih baik. Guru dapat memperlakukan siswa secara adil, berlaku demokratis, dan berkembang suasana yang fair sehingga dapat memacu kreativitas siswa. Suasana pembelajaran akan menjadi lebih kondusif, berkembang daya pikir kritis dan mengembangkan daya imajinasi siswa. Hasil penelitian yang pernah dilakukan (Sudrajat, 2011) menunjukkan bahwa implementasi berbasis multikultural dapat meningkatkan motivasi belajar karena siswa merasa mempunyai teman yang menyenangkan di sekolah. Mereka juga merasa diperhatikan oleh gurunya sehingga memotivasi mereka untuk meningkatkan prestasi belajarnya.

\section{E. Simpulan}

Indonesia merupakan negara multikultur dengan jumlah etnis, kultur, bahasa, agama, dan latar belakang yang sangat beragam. Namun sayangnya kesadaran akan multikulturalisme dalam masyarakat kita belum berkembang dengan semestinya. Oleh karenanya tidak mengherankan apabila konflik antar etnis serta antar agama sering terjadi di republik ini. Pemerintah sepertinya kurang tepat dalam menangani konflik karena selalu menggunakan pendekatan politis-hukum, padahal pendekatan yang demikian sifatnya parsial dan berpotensi menimbulkan permasalahan baru berupa ketidakpuasan dari masyarakat terhadap keputusan pengadilan.

Pendidikan merupakan solusi untuk mengurai benang kusut konflik berkepanjangan berkat peranannya sebagai social reconstruction. Implementasi pendidikan multikultur yang menekankan pada pentingnya kesadaran terhadap adanya perbedaan memerlukan komitmen dari semua elemen masyarakat karena memerlukan reformasi paradigma pendidikan.

Pemangku kepentingan khususnya dalam dunia pendidikan harus mempunyai komitmen yang kuat serta kesadaran yang tinggi untuk mendukung implementasi pendidikan multikultur. Lebih jauh lagi guru harus bersedia melakukan transformasi diri dan restropeksi diri untuk mempersiapkan dirinya mengawal dan mengajar dengan basis multikultural. Guru harus mendapat bimbingan dan arahan agar dapat berperan secara maksimal sehingga pendidikan multikultural dapat diimplementasikan dengan baik. 


\section{Daftar Pustaka}

Banks, James A. (2005). Multicultural education: issues and perspectives. New Jersey: John Willey \& Son Inc.

Banks, James A. (2007). Educating citizens in a multicultural society. New York: Teachers College Columbia University.

Bruch, Patrick L; Highbee Jeanne L; Lundell, Dana Britt (2004) Multicultural education and developmental education: A conversation about principles and connections with James A Banks. Research E Teaching In Developmental Education, I, 3-17.

Choirul Mahfud. (2010). Pendidikan multikultural . Yogyakarta: Pustaka Pelajar.

Farida Hanum. Pendidikan multikultural dalam pluralismebangsa. tersedia dalam http: eprints. uny.ac.id. Diunduh tanggal 25 Desember 2012.

Firdaus M. Yunus. (2007). Pendidikan Berbasis Realitas Sosial: YB Mangunwijaya- Paulo Freire. Yogyakarta: Logung Pustaka.

Hammond, Linda Darling. Jennifer French \& Silvia Paloma Garcia Lopez (ed.) (2002). Learning to teach for social justice. New York: Teachers College Columbia University.

Kaswardi, EM. K., ed. (1993). Pendidikan Nilai Memasuki Tahun 2000. Jakarta: Grasindo.

Kymlicka, Will \& Baogang He. (2005). Multiculturalism in Asia. Oxford: Oxford University Press.

Lisa, A Jones. (2004). Teaching citizenship through multicultural education. Kappa Delta Pi Record, I, 17-21.

Sudrajat (2011). Pendidikan berbasis multikultural untuk meningkatkan kualitas pembelajaran IPS di SD; Laporan Penelitian; Yogyakarta: FIS UNY.

Tatang M Amirin. (2012). Implementasi pendekatan pendidikan multikultural kontekstual berbasis kearifan lokal. Jurnal Pembangunan Pendidikan: Fondasi dan Aplikasi, I, 1-16.

Zamroni (2007). Pendidikan dan demokrasi dalam transisi (prakondisi menuju era globalisasi. Jakarta: PSAP Muhammadiyah.

Zamroni (2011a). Pendidikan untuk demokrasi: Tantangan menuju civil society. Yogyakarta: Bigraf publishing.

Zamroni (2011b). Pendidikan demokrasi pada masyarakat multikultur. Yogyakarta: Gavin Kalam Utama.

Zamroni. (2000). Paradigma Pendidikan Masa Depan. Yogyakarta: Bigraf Publishing. 